\title{
Ultrasonographic Assessment Of Collateral Cerebral Circulation In Patient With Internal Carotid Artery Occlusion
}

\begin{abstract}
Cerebrovascular diseases represent a serious global health problem. They are the leading cause of disability and second cause of death worldwide. Identification of risk factors and early diagnosis allow prompt prevention and treatment. Group of authors, through a case report of a patient with a symptomatic internal carotid artery occlusion and an overview of diagnostic and therapeutic protocol, alludes to the advantages of ultrasonographic diagnosis not only with diagnosis itself but with the subsequent patient's follow-up. Ultrasonographic diagnosis is completely sufficient with respect to more expensive and invasive diagnostic procedures and it provides a complete insight of brain circulation in real time. When it comes to the assessment of collateral brain circulation, ultrasonographic diagnosis is the method of choice.
\end{abstract}

KEY WORDS: Color Doppler Ultrasound, occlusion, internal carotid artery, collateral cerebral circulation

DOI: 10.7251/SMD1402082V

(Scr Med 2014:45:87-90)

\section{Zoran Vujković, Siniša Miljković ${ }^{1}$, Vlado Đajić ${ }^{1}$, Duško Račić, Srđan Mavija ${ }^{1}$, Saša Dragić ${ }^{1}$}

${ }^{1}$ Clinic of Neurology, University Hospital Clinical Center Banja Luka

\section{Contact address:}

Siniša Mijković

Klinika za neurologiju

Univerzitetska bolnica "Klinički cen-

tar" Banja Luka

12 beba bb, $780 o o$ Banja Luka

Telephone no: 38765681681

E-mail:neurologija@blic.net

Submitted: September 16th, 2014 Accepted: October 10th, 2014

\section{Introduction}

Cerebrovascular diseases represent a serious public health problem. They are the leading cause of disability and second cause of death worldwide. ${ }^{1}$

The World Health Organization defines stroke as rapid development of clinical signs in terms of focal or global disturbance of cerebral function, with symptoms lasting 24 hours or longer or leading to death, without any other apparent cause other than signs of blood vessel damage.

We differentiate two types of stroke, and these are ischemic - due to thrombosis, emboli , or systemic hypoperfusion ( $80 \%$ of cases ), and hemorrhagic which causes bleeding ( $20 \%$ ) . Approximately $50 \%$ of ischemic strokes are related to atherosclerotic disease of the intracranial or extracranial parts of the carotid artery. ${ }^{2}$
The atherosclerotic disease of extracranial carotid artery itself is responsible for about 15 to $20 \%$ of ischemic strokes. ${ }^{3}$

The annual incidence rate for occlusion of the internal carotid artery is 6/100000 residents. ${ }^{4}$

Age, arterial hypertension, cigarette smoking, hyperlipidemia, diabetes, gender, and fibrinogen are the main risk factors for development of the atherosclerotic process in the carotid vessels, and they also correlate with the severity of stenosis. ${ }^{1,5-7}$

Ultrasonographic monitoring is the most important diagnostic tool in stenosis - occlusion monitoring, as well as in controlling the establishment of collateral cerebral circulation. ${ }^{8}$ 


\section{A case report}

Patient S.A., aged 56, male, was examined in a walk-in neurology center at 11: 40h. On the same day, at about 10: $10 \mathrm{am}$, the patient felt a sudden weakness in his left arm and left leg. During the ambulance transport to the clinic, the deficit had withdrawn from bold to mild ( NIHSS 2 ), and on the initial examination, the patient only complained of headache in the right frontal region. Immediately upon the reception, the patient was referred to CT analysis of endocranium whish shows only separate microvascular ischemic lesions in the region of internal capsule, subcortinal, insular bilaterally (Figure 1.).

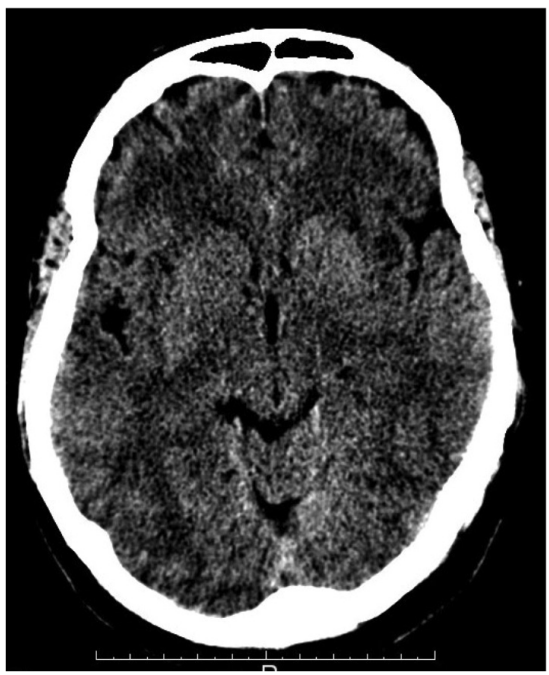

Figure 1. Ct analysis of endocranium before thrombolysis normal findings

After returning from the $\mathrm{CT}$, once again, the plegia of the left extremities occurred, and the protocol for thrombolysis, within which laboratory analysis was done, was immediately initiated ( $\operatorname{Tr}$ 179: INR 1.08: APTT 28.8 " : blood sugar 5.85 ) and TCCD : Occlusion ACI dex (in syphon ) vsml .

The neurological status upon the admission to the stroke unit showed deviation of the head and right side look, the central facioparesis on the left, with dysphasia and plegia of the left extremities RANKIN 5 , NIHSS 16).

Uncontrolled hypertension and atherosclerotic altered vessels were the sole identified risk factors.

Since all inclusion criteria stipulated by the protocol were fulfilled, therapy at a dose of $0.9 \mathrm{mg} / \mathrm{kg}$ body weight, with a total dose of $90 \mathrm{mg}$, that being the maximum dose (the patient weighs $112 \mathrm{~kg}$ ) was given. After receiving thrombolytic therapy, partial withdrawal of neurological deficit occurred and diagnosis, symptomatic treatment and secondary prevention of stroke continued in postliminary hospitalization.

The next day of hospitalization, the CT of the head was repeated and it showed acute ischemic lesions in supratentorial, frontoparietal and the right posterior (Figure 2.).

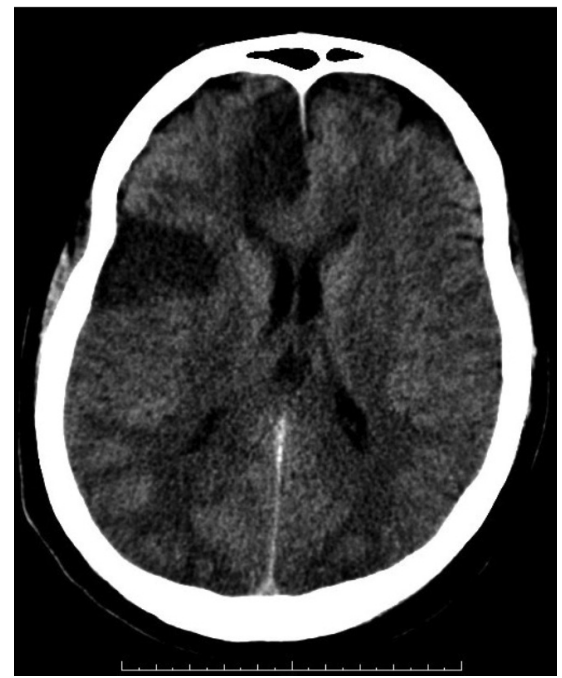

Figure 2. Ct scan after thrombolysis - a heart attack in the area of vascularization of ACA and right MCA

Furthermore, the CTA of blood vessels of the head was done and the scan showed the occlusion by soft tissue thrombus of distal two-thirds of the cervical segment of the right ICA with minimal filiform display as the consequence of retrograde flow. In the petrous part there was no flowtotal occlusion ( Figure 3.).

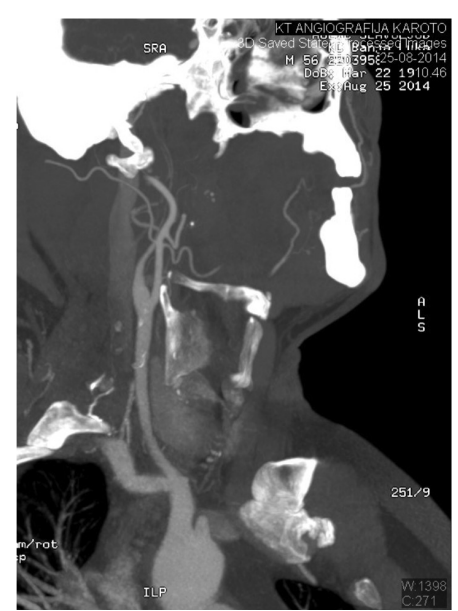

Figure 3. CTA of the neck - occlusion of the right $\mathrm{ACl}$ (in syphon) 
As the method of choice in the follow-up of the cerebral circulation, we chose TCCD which showed that the internal carotid artery (in the syphon), with a developed collateral circulation through posterior communicant artery and equilateral ophthalmic arteries was still present (Figure 4.).

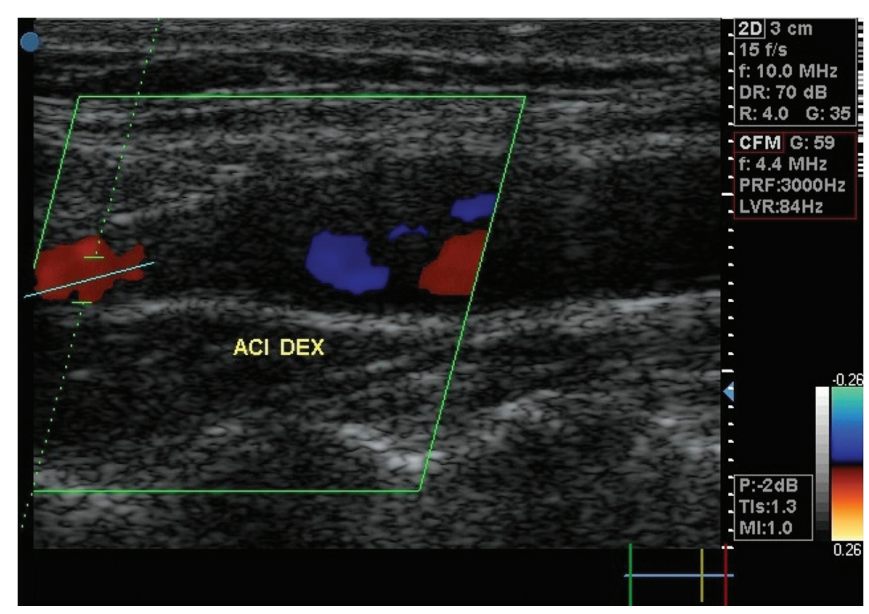

Figure 4. Right $\mathrm{ACl}$ immediately after the birufication

In addition to thrombolytic therapy, the patient was treated with infusions of rehydration solutions, low molecular weight heparin, antiagregantes, antihypertensives, sedatives, and antibiotics due to uroinfect.

Under the supervision of a physiatrist, intrahospital early physical therapybegan, and on the $14^{\text {th }}$ day of hospitalization, the patient was discharged in order to continue his early rehabilitation in the Institute of Physical Medicine and Rehabilitation "Dr Miroslav Zotović" Banja Luka. At the discharge, the neurological examination showed a tail of severe left-sided hemiparesis with partial functional recovery (RANKIN 5; NIHSS 9), together with a well-developed collateral circulation via the posterior communicant artery and the equilateral ophthalmic artery.

\section{Discussion}

Ultrasonographic displey of the carotid vessels is noninvasive and objective method for the evaluation of cerebral hemodynamics. Extracranial Color Doppler provides important information regarding the state of the carotid and vertebral arteries, intima - media complex thickness (IMT - intima media thickness) as an important indicator for the development of atherosclerosis - accommodation, position, length, layout and content of the plaque.

Ultrasonography can accurately estimate the degree of stenosis of the carotid artery, which is correlated with angiographic findings obtained using DSA or MSCT (these techniques bring certain percentage of complications). Accordingly, this method should be used exclusively in patients in whom stenosis of sonographic carotid artery fails to be adequately neurosonologicaly displayed. In the case of pseudo occlusion probably due to the density of contrast, angiography is not sensitive enough in relation to ultrasound. Then the Power Doppler may be used.

Additional advantage of an ultrasound is the possibility to measure the flow rate in a blood vessel itself, but also in collateral brain circulation. Doppler findings best correlate with DSA, whereas in the studies where the correlation with the macroscopic findings after the surgical treatment has been monitored, it has been proven that MSCTA underestimates the degree of stenosis, while MRA overestimates it. ${ }^{9,10}$

In this precise case report described by the authors, ultrasound is the method of choice not only in diagnosis but in the follow-up as well. They made an appointment for ultrasonography check-up of the patient in 3 months.

\section{Conclusion}

After the thrombolytic therapy in the presented case report, there was no sign of recanalization of the vessel but the establishment of described collateral circulation and partial functional recovery occurred.

The presented case report showed that the ultrasound findings correlated to the findings of more sophisticated, more invasive and expensive procedures.

Screening programs for the evaluation of asymptomatic carotid disease, based on ultrasonographic display, are of great significance for the primary prevention of stroke, and thereby for reduction of the specific rate of mortality and disability.

Ultrasonographic diagnosis is completely sufficient in relation to more expensive and invasive diagnostic procedures and it provides a complete insight into the state of the cerebral circulation in real time.

\section{References}

1. Lovrenčić-Huzijan A, Strineka M, Ažman D, Štrbe S, ŠodecŠmičević D, Demarin V. The contralateral carotid disease in patient with internal carotid artery occlusion. Acta Clin Croat 2009; 48: 241-6.

2. World Health Organisation.Cerebrovascular disorders (Offset Publications). Geneva: World health Organisation, Geneva, 1978. ISBN 9241700432.

3. Strenja-Linić I, Kovačević M, Kovačić S et al. Clinical presentation, diagnostics and guidelines in treatment of patient with carotid artery stenosis. Medicina fluminensis 2013; 49(1): 17-30.

4. Flaherty ML, Flemming KD, McClelland R, Jorgensen NW, Brown RD. Population based study of symptomatic internal carotid artery occlusion. Stroke 2004; 35:1785-2011. 
5. Mathiasen EB, Joakimsen O, Boana KH. Prevalence of and risc factors associated with carotid artery stenosis: the Tomso Study. Cerebrovasc Dis 2001; 12: 44-51.

6. Paraskevas PI, Mikhailidis DP. Internal carotid artery occlusion: association with atherosclerosis disease in other arterial beds and vascular risc factors. Angiology 2007; 58:329-35.

7. Alexander JJ, Moawad J, Super D. Outcome analysis of carotid artery occlusion. Vasc EndovascSurg 2007; 41: 409-16.

8. AbuRahma AF, Metz MS, Robinson PA. Natural history of $>$ or $=60 \%$ asymptomatic carotid stenosis in patient with contralateral caroid occlusion. An Surg 2003; 238: 551-61.
9. Grant EG, Benson CB, Moneta GL, Alexandrov AV, Baker JD, Bluth EI et al. Carotid artery stenosis: gray-scale and Doppler US diagnosis-Society of Radiologist in Ultrasound Consensus Conference. Radiology 2003; 229: 340-6.

10. Patel SG, Collie DA, Wardlaw JM, Lewis SC, Wright AR, Gibson $\mathrm{RJ}$ et al. Outcome, observer reliabillity, and patient preferences if CTA, MRA, or Doppler ultrasound were used, individually or together, instead of digital subtraction angiography before carotid endarterectomy. J Neurol Neurosurg Psychiatry 2002; 73: 21-8.

\section{Ultrasonografsko praćenje kolateralne moždane cirkulacije kod pacijenta sa okluzijom unutrašnje karotidne arterije}

\section{SAŽETAK}

Cerebrovaskularne bolesti predstavljaju ozbiljan globalni zdravstveni problem. Na prvom su mjestu kao uzrok invaliditeta, a na drugom kao uzrok smrti u svjetskoj populaciji. Identifikacija faktora rizika i rana dijagnostika omogućavaju prevenciju i pravovremeno liječenje. Grupa autora, kroz prikaz slučaja pacijenta sa simptomatskom okluzijom unutrašnje karotidne arterije, te prikazom dijagnostičkog i terapijskog protokola, skreće pažnju na prednosti ultrasonografske dijagnostike kako u postavljanju dijagnoze tako i u daljem praćenju pacijenta. Ultrasonografska dijagnostika je potpuno suficijentna u odnosu na skuplje i invazivnije dijagnostičke procedure i pruža potpun uvid u stanje moždane cirkulacije u realnom vremenu. Ultrasonografska dijagnostika je je metoda izbora u procjeni kolateralne cirkulacije.

\section{KLJUČNE RIJEČI:}

kolor Dopler ultrazvuk, okluzija, unutrašnja karotidna arterija, kolateralna moždana cirkulacija 